ISSN 2413-0877 Volume 2 (2015) 504

The 3rd International Conference on Biological Science 2013

(The 3rd ICBS-2013)

\title{
DUGONG (Dugong dugon) FEEDING BEHAVIOUR IN SEA WORLD INDONESIA, TAMAN IMPIAN JAYA ANCOL, JAKARTA
}

\author{
Abdul Jamaludin ${ }^{1}$, Luthfiralda Sjahfirdi ${ }^{1}$, Riani Widiarti $^{1}$ \\ ${ }^{1}$ Departement of Biologiy, Faculty of Mathemathic and Natural Science, \\ University of Indonesia, Depok \\ Email abdul.jamaludin@ymail.com
}

\begin{abstract}
Dugongs is a protected herbivorous marine mammals (Suwelo et al., 1992) and included in vulnerable category of IUCN (International Union for the Conservation of Nature and Natural Resources) and Appendix I CITES (Convention on International Trade in Endangered Species) (IUCN 2012). Dugong population continues to decline due to the human threat (Suwelo et al., 1992). Another factor is because Dugong has a low reproductive rate (Hindell \& Kirkword 2003). Ex-situ conservation of dugong is become important and has conducted by Sea World Indonesia, Taman Impian Jaya Ancol, Jakarta. Research on dugong feeding behaviour can help the ex-situ conservation of dugong. This because feeding behaviour is a main daily behaviour of dugong in the sea (Chilvers et al., 2003). The aim of this research was to describe feeding behaviour of two dugong in Sea World Indonesia. Observations were made in SWI Dugong aquarium with a diameter of 10 meters and two different depth (2 meters and 5 meters). Observations were made during two weeks on December 2012. Behavioral observation time was divided into morning (9:15 to 09:35), (11:30 to 11:50) and (14:30 to 14:50) observations. The feeding behavior observed was hand-fed, surface-fed and bottom-fed. Daily observations of dugong feeding behavior were done using focal animal sampling and ad libitum sampling. The data obtained was displayed in the form of tables and graphs. The data was analyzed using descriptive analysis reinforced with statistical tests. The statistical tests used were the t-test and ANOVA test. Hand-fed behavior of male dugong $(31,30 \%)$ was higher than female $(29,67 \%)$. Results from t-test showed that the hand-fed behaviors of both dugongs were not significantly different. Meanwhile, the other t-test result for surface-fed behavior and bottom-fed behavior of both dugongs was significantly different. Surface-fed behavior of male dugong $(65.83 \%)$ was higher than female $(32.08 \%)$. Bottom-fed behavior of male dugong $(6.23 \%)$ was lower than females $(36.63 \%)$. Hand-fed behaviour and feed on surface are the adaptation of feeding behavior in captivity. Feed on bottom behaviour is the behavior that similar to dugong feeding in the wild, which is grazing. Based on the observation, it is known that both dugong, male dugong especially, have a good adaptation on hand-fed seagrass behaviour and feed on surface, while the female dugong maintain its natural feeding behavior.
\end{abstract}

Key words: Dugong dugon, Sea World Indonesia, feeding behaviour, captive

IISSN 2413-0877 (C) 2015 The Authors.

Published by KnowledgeE Publishing Services This is an open access article under the CC BY-NC-ND license (http://creativecommons.org/licenses/by-nc-nd/4.0)

Selection and Peer-review under responsibility of the 3rd ICBS-2013

Doi http://dx.doi.org/10.18502/kls.v2i1.204 